\title{
DOES GSTP1 POLYMORPHISM CONTRIBUTE TO GENETIC DAMAGE CAUSED BY AGEING AND OCCUPATIONAL EXPOSURE?
}

\author{
Sima Ataollahi ESHKOOR ${ }^{1}$, Patimah ISMAIL ${ }^{1}$ Sabariah Abd RAHMAN ${ }^{1,2}$, and Saidi MOIN ${ }^{1}$ \\ Faculty of Medicine and Health Sciences ${ }^{1}$, Institute BioSciences ${ }^{2}$, Universiti Putra Malaysia, UPM Serdang, \\ Selangor, Malaysia
}

Received in January 2011

CrossChecked in July 2011

Accepted in July 2011

\begin{abstract}
The aim of our study was to see the effects of GSTP1 polymorphism on biomarkers of ageing, including micronuclei (MN), comet tail length, and relative telomere length in automobile repair workers, who are exposed to a broad spectrum of potential mutagens. The analysis was performed on buccal cells collected from occupationally exposed and non-exposed (control) subjects. Samples were analysed using cytogenetic and molecular methods, including restriction fragment length polymorphism (RFLP), MN test, comet assay, and real-time PCR. The results confirmed the DNA damaging effects of substances used in the mechanical workshops, but did not confirm the influence of GSTP1 gene polymorphism on DNA damage. However, further studies on both occupationally exposed and control populations are needed to understand the relationship between GSTP1 polymorphism and genome damage.
\end{abstract}

KEY WORDS: buccal cells, comet tail length, glutathione S-transferases, micronucleus frequency, PCR, RFLP, telomere length

DNA damage resulting from exposure to mutagens is a major threat to the living cell (1). Ageing is an interaction between genetic and environmental factors, which takes place at the cellular level. Cellular ageing seems to be related to nuclear and mitochondrial DNA damage and diminished DNA repair (2). It is responsible for increased susceptibility to disease and increased death rate, which accompany advanced age (3). Aware of the association between advanced age and disease and death, researchers have continued to provide information about ways to support healthy life. The useful span of human life has been extended by slowing down the rate of ageing (4). According to Wojda (2), accumulation of cells at the end of their replicative life in the elderly contributes to the ageing of the tissue. How exactly this accumulation of senescent cells contributes to ageing is still unknown
(5), but it is reasonable to assume that many organs become dysfunctional because their cells have lost or altered their function. Wojda (2) believes that multiple acting genes control replicative senescence.

Accumulated mutations resulting from DNA replication over a long period of time play an important role in ageing. These mutations are irreversible, which in many cases can be harmful. Unsafe mutations will become toxic to cells (6). Glutathione $S$-transferase (GST) detoxifies potentially mutagenic and toxic DNA-reactive electrophiles, including the metabolites of several chemotherapeutic agents (7). Its gene families include GSTM1, GSTT1, and GSTP1. The homozygous deletions of GSTM1 and GSTT1 (null genotypes) have no enzymatic activities (8). In contrast, GSTP1, located on chromosome 11q13, is involved in detoxifying environmental compounds. 
However, its I105V polymorphism - with a switch from isoleucine to valine at codon 105 in exon 5 seems to reduce the enzyme activity (9).

The aim of this study was to evaluate the effects of occupational exposure on DNA damage under the possible influence of GSTP1 I105V polymorphism in exposed car repair workers and controls, as current data (10) suggest that the interaction between this gene polymorphism and genotoxic effects of exposure could speed up ageing.

\section{MATERIALS AND METHODS}

\section{Sample collection}

This study was approved by the ethics committee of the Faculty of Medicine and Health Sciences (Reference Number: UPM/FPSK/PADS/T7MJKEtikaPer/F01 (JSB-Aug (08)05). Samples were collected from 120 exposed workers from car repair workshops and 120 unexposed controls. None of the occupationally exposed subjects wore gloves. None of the workshops had proper ventilation. The subjects were interviewed to evaluate their health status and lifestyles. They were asked to rinse their mouth with water before samples were collected. Epithelial cell samples were collected by scraping the inner part of both sides of the cheeks with a cytology brush. The cells were then gently mixed with $1.5 \mathrm{~mL}$ of $0.9 \%$ sodium chloride and PBS in a micro-centrifuge tubes, taken to the laboratory and prepared for the micronucleus (MN) testing, comet assay, real-time polymerase chain reaction (PCR), and restriction fragment length polymorphism (RFLP).

\section{Micronucleus test}

The cells were smeared on slides, dried, and fixed with a cold solution of $1 \%$ glutaraldehyde in $0.1 \mathrm{~mol} \mathrm{~L}^{-1}$ phosphate buffer $(\mathrm{pH}=7.5)$ for $20 \mathrm{~min}$. The slides were stained with Feulgen reagent using a modified protocol by Beliën et al. (11). First the cells were hydrolysed in $5 \mathrm{~mol} \mathrm{~L}^{-1} \mathrm{HCl}$ at $27^{\circ} \mathrm{C}$ for $30 \mathrm{~min}$. The slides were then washed in distilled water for $5 \mathrm{~min}$ and then stained with a fresh Schiff reagent (Sigma Chem, Japan) within 45 min. Finally, the slides were washed under tap water for $15 \mathrm{~min}$, counterstained with $0.1 \%$ naphtol-yellow (Sigma-Aldrich, India) within $20 \mathrm{~s}$, and air-dried overnight. To determine MN frequency for each sample, 2000 cells were analysed under a light, dry lens microcope at 200x magnification (Nikon, Japan).

\section{Comet assay}

The comet assay was used to determine the extent of DNA damage in the cells. We used the Trevigen CometAssay ${ }^{\mathrm{TM}}$ kit protocol (Trevigen, USA). The assay was started immediately after the cells were prepared. As a precaution, all work must be done under dim light to prevent DNA damage from UV rays. The cells were combined with LM agarose at $37^{\circ} \mathrm{C}$ at the ratio of $1: 10$, and $75 \mu \mathrm{L}$ aliquots were immediately pipetted onto the slides. The slides were prepared in duplicate and placed flat in a dark place at $4{ }^{\circ} \mathrm{C}$ for $10 \mathrm{~min}$. The slides were then immersed in the prechilled lysis solution (Trevigen, USA) for $60 \mathrm{~min}$, followed by immersion in a freshly prepared alkaline solution, $\mathrm{pH}>13$, at room temperature in the dark for $45 \mathrm{~min}$. After that, the slides were placed flat on a gel tray. Electric power was set at $1 \mathrm{~V} \mathrm{~cm}^{-1}$ (measured from electrode to electrode) and applied for $10 \mathrm{~min}$. The slides were then completely stained with $50 \mu \mathrm{L}$ of diluted SYBR Green (Trevigen, USA) before viewing with a fluorescent microscope DM 2500 (Leica, Germany) at 200x magnification, and the images were captured. The cells were analysed using commercial TriTek Comet Score (version 1.5) software (TriTek Corp., Sumerduck, VA, USA). Tail lengths of the comets were determined from the centre of the head towards the last visible signs at the end of the tail and are expressed in micrometres.

\section{DNA extraction}

Genomic DNA was extracted from the cells using the QIAamp DNA blood miniKit (Qiagen, Courtaboeuf, France). The purity and the concentration of extracted DNA were quantified using a Nanodrop ${ }^{\mathrm{TM}} 1000$ spectrophotometer (Thermo Scientific, USA) and the DNA was run on a $0.7 \%$ to $1 \%$ agarose gel. PCR reaction was performed to optimise the primers.

\section{Real-time PCR}

Real-time PCR was used to measure relative telomere length. The used primers were telomere and 36B4, as described earlier by Cawthon (12). The primer sequences were: tell, GGTTTTT GAGGGTGAGGGTGAGGGTGAGGGT GAGGGT; te 12, TCCCGACT-ATC CCTATCCCTAT CCCTATCCCTA TCCCTA; 36B4u, CAGCAA GTGGGA AGGT-GTAATCC; 36B4d, and CCCA 
TTCTATCA TCAACGGGTACAA. The telomere repeat copy number to single gene copy number $(\mathrm{T} / \mathrm{S})$ ratio was determined using the Corbett Rotor-Gene 6000 (Corbett Life Science, Sydney, Australia) with 36 wells. For PCR reaction, a $25 \mu \mathrm{L}$ volume of solution was prepared in PCR tubes. In each run, both gene telomere and 36B4 were settled for one sample in separate tubes. Primers were obtained from Bioline (London, UK).

The solution for PCR reaction included $0.6 \mu \mathrm{L}$ of each primer, $1 \mu \mathrm{L}$ of Eva green, $1 \mu \mathrm{L}$ of DNA, $5 \mu \mathrm{L}$ of master mix Immomix (Bioline, London, UK), and $16.8 \mu \mathrm{L}$ of pure water. The reaction consisted of 41 cycles; the first started with incubation at $94{ }^{\circ} \mathrm{C}$ for $5 \mathrm{~min}$, followed by denaturation at $94{ }^{\circ} \mathrm{C}$ for $30 \mathrm{~s}$, annealing at $56^{\circ} \mathrm{C}$ for $30 \mathrm{~s}$, and extension at $72{ }^{\circ} \mathrm{C}$ for $50 \mathrm{~s}$. Melting temperature was $70{ }^{\circ} \mathrm{C}$ to $95^{\circ} \mathrm{C}$. The data obtained from the samples were interpreted throughout the dataset to assess threshold cycle values. After the reaction, the product size was $76 \mathrm{bp}$ for the telomere and $74 \mathrm{bp}$ for 36B4.

\section{PCR reaction}

PCR reaction was performed to provide the product for RFLP. First it was used to optimise the applied primers. Forward and reverse primers have already been described by Harries et al. (13). Primer sequences were: sense, 5'-ACCCCAGGGCTCTATGGGAA-3' and anti-sense, 5'-TGAGGGCACAAGAAGCCCCT-3'. The solution volume in the PCR tube was $25 \mu \mathrm{L}$. Immomix master mix (Bioline, London, UK) containing dNTPs, Taq polymerse, $\mathrm{MgCl}_{2}$, and a buffer were applied to PCR reactions. To prepare the product, each tube received $5 \mu \mathrm{L}$ of Immomix master mix, $0.6 \mu \mathrm{L}$ of primer, $2 \mu \mathrm{L}$ to $6 \mu \mathrm{L}$ of genomic DNA, and $12.8 \mu \mathrm{L}$ to $16.8 \mu \mathrm{L}$ of pure water. The tubes were placed in a G-Storm Thermal Cycler (Gene technology Ltd, UK) for PCR reaction.

The PCR reaction was performed in 35 cycles. The first cycle started with incubation at $94^{\circ} \mathrm{C}$ for $5 \mathrm{~min}$, followed by denaturation at $94{ }^{\circ} \mathrm{C}$ for $30 \mathrm{~s}$, annealing at $62{ }^{\circ} \mathrm{C}$ for $30 \mathrm{~s}$, extension phase at $72{ }^{\circ} \mathrm{C}$ for $45 \mathrm{~s}$, and the final extension at $72{ }^{\circ} \mathrm{C}$ for $10 \mathrm{~min}$ after the last cycle. Proper annealing temperature was obtained through gradient PCR analysis. After completing amplification, the samples were stored at $4{ }^{\circ} \mathrm{C}$ until use. A negative control without DNA template was carried out in every run. The specific PCR product was identified by running $1.8 \%$ to $2 \%$ agarose gel electrophoresis, and the gel was then viewed with an
AlphaImager analysis system (Alpha Innotech, San Leandro, CA). The product size was $176 \mathrm{bp}$.

\section{RFLP reaction of GSTP1}

Fifteen microlitres of PCR reaction product was put aside for RFLP. First we added 7.2 $\mu \mathrm{L}$ of $\mathrm{ddH}_{2} \mathrm{O}$ to the PCR tube, then $1.5 \mu \mathrm{L}$ of restriction enzyme buffer, and then $6.0 \mu \mathrm{L}$ of purified PCR product. Finally we added $0.3 \mu \mathrm{L}$ of ALW26I restriction enzyme (10 units per $\mu \mathrm{L}$; Fermentas, USA). The mixture was gently pipetted up and down to mix the solution well. The reaction mixture was incubated in a heating block at $37^{\circ} \mathrm{C}$ for $16 \mathrm{~h}$. After incubation, the enzyme was inactivated by incubating in the same heating block at $65^{\circ} \mathrm{C}$ for $20 \mathrm{~min}$.

\section{Determination of products}

Agarose gel electrophoresis identified PCR and RFLP products sizes. Gels used for PCR and RFLP were $2 \%$ and $4 \%$, respectively. We also used DNA ladders of $50 \mathrm{bp}$ and $100 \mathrm{bp}$ (Bioline, London, UK) to identify product size. Finally the gel was viewed under UV light using the AlphaImager TM 2200 system.

\section{Statistical analysis}

The normality of variables was evaluated using the Kolmogorov-Smirnov test. The Mann-Whitney U-test, independent t-test, and ANOVA were used to compare the demographic characteristics of study populations. Differences in MN frequency and DNA damage measured by the comet assay were tested using the non-parametric Mann-Whitney U-test. Telomere length measurements were tested using the independent $t$-test. Gene frequencies were estimated by gene counting, and Hardy-Weinberg equilibrium was evaluated using the chi-square test for goodness of fit adjusted for samples. The critical level for rejection of the null hypothesis (two-tailed test) was the $\mathrm{p}$ value of $5 \%(\mathrm{p}=0.05)$. All analyses were performed using the Statistical Package for the Social Sciences (SPSS, Chicago, IL) software version 16.0 .

\section{RESULTS}

Figures 1 and 2 are the images PCR and RFLP products of the GSTP1 gene. The GSTP1 gene was amplified by PCR reaction and the product was in the size of 176 bp (Figure 1). RFLP products of GSTP1 


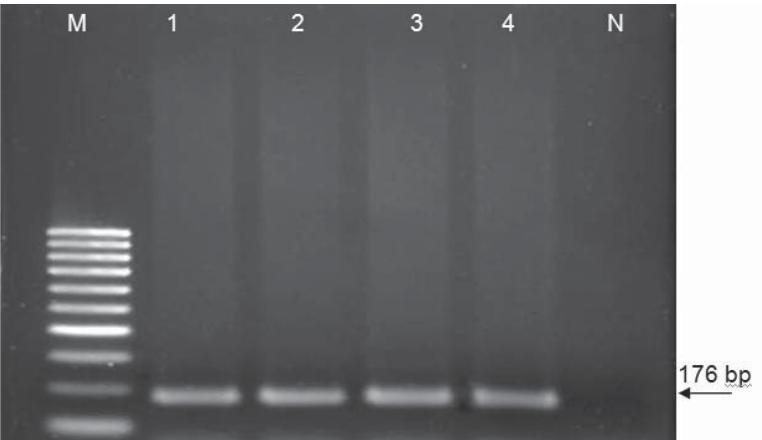

Figure $1 P C R$ product of GSTP1 gene run on a 2-percent agarose gel in samples 1 to $4 . M$ is a $100 \mathrm{bp}$ DNA ladder. $N$ is negative control in $P C R$ reaction.

using ALW26I restriction enzyme were Ile-Ile (176 bp), Ile-Val (176 bp, $91 \mathrm{bp}$, and $85 \mathrm{bp}$ ) and ValVal (91 bp and $85 \mathrm{bp}$ ) (Figure 2). The products were identified as wild and mutated. Ile-Ile genotype was placed in the wild group and Ile-Val and Val-Val were in the mutated group. The respective frequencies of Ile-Ile, Ile-Val, and Val-Val genotypes were $60.0 \%$, $30.4 \%$, and $9.6 \%$ in all subjects. Gene polymorphism did not significantly influence $(\mathrm{p}>0.05)$ individual biomarkers (Table 1). Workers with the mutated genotype (Ile-Val, Val-Val) had a significantly higher MN frequency $(p<0.001)$, shorter telomere length $(\mathrm{p}=0.008)$, and greater comet tail length $(\mathrm{p}=0.025)$ than controls. The same is true for workers with the wild genotype Ile-Ile, save for the comet tail length

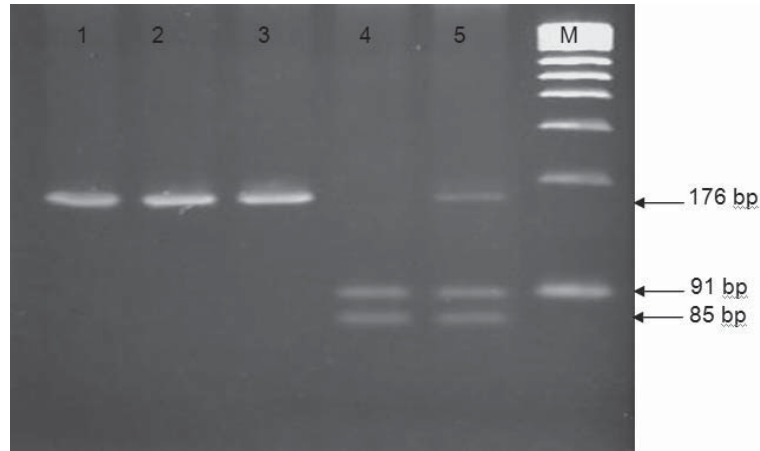

Figure 2 Restriction fragments of GSTP1 gene run on a 4percent agarose gel in samples of 1 to $5 . M$ is a $100 \mathrm{bp}$ DNA ladder. Lanes 1, 2, and 3 show that the enzyme has no restriction site (176 bp). Lane 4 shows that the enzyme produced two fragments of this gene (91 bp, $85 \mathrm{bp})$. Lane 5 shows that the enzyme produced three fragments of this gene $(176 \mathrm{bp}, 91 \mathrm{bp}$, and $85 \mathrm{bp}$ ).

(Table 2). When workers and controls were divided by age into groups below 30 years and above, gene polymorphism did not significantly affect the studied biomarkers. However, the mutated genotype showed a significant effect on $\mathrm{MN}$ frequency $(\mathrm{p}=0.021)$ in the control group as a whole (see Table 3 control MN frequency, $\mathrm{p}=0.021$ ).

Smoking, alcohol consumption, and educational level showed no statistically significant effect on MN frequency, comet tail length, and telomere length, but ethnicity had a significant effect on MN frequency

Table 1 Effect of GSTP1 genotypes on the biomarkers in the individuals

\begin{tabular}{|c|c|c|c|c|}
\hline \multirow{2}{*}{$\begin{array}{l}\text { Biomarkers } \\
\text { GSTP1 genotypes }\end{array}$} & \multirow{2}{*}{$\mathbf{N}$} & MN & Comet tail length & Relative telomere length \\
\hline & & $\mathbf{p}$ & $\mathbf{p}$ & $\mathbf{p}$ \\
\hline Ile-Ile & 144 & \multirow{2}{*}{0.481} & \multirow[t]{2}{*}{0.984} & \multirow{2}{*}{0.763} \\
\hline (Ile-Val, Val-Val) & 96 & & & \\
\hline
\end{tabular}

Mann-Whitney U-test was used for DNA damage and MN-test and t-test for telomere length

Table 2 Effect of GSTP1 genotypes on the biomarkers between the workers and controls

\begin{tabular}{|c|c|c|c|c|c|c|c|c|}
\hline \multirow{2}{*}{$\begin{array}{l}\text { Biomarkers } \\
\text { GSTP1 } \\
\text { genotypes }\end{array}$} & & \multirow{2}{*}{$\mathbf{N}$} & \multicolumn{2}{|l|}{ MN } & \multicolumn{2}{|c|}{ Comet tail length } & \multicolumn{2}{|c|}{ Relative telomere length } \\
\hline & & & $\operatorname{Mean} \pm$ SD & $\mathbf{p}$ & $\operatorname{Mean} \pm$ SD & $\mathbf{p}$ & Mean \pm SD & $\mathbf{p}$ \\
\hline \multirow[b]{2}{*}{ Ile-Ile } & Workers & 78 & $12.21 \pm 4.57$ & \multirow{2}{*}{$<0.001$} & $25.21 \pm 9.52$ & \multirow{2}{*}{0.120} & $0.30 \pm 0.67$ & \multirow[b]{2}{*}{0.019} \\
\hline & Controls & 66 & $2.13 \pm 1.68^{*}$ & & $16.70 \pm 7.62$ & & $2.65 \pm 7.94$ & \\
\hline \multirow{2}{*}{ (Ile-Val, Val-Val) } & Workers & 42 & $12.45 \pm 3.92$ & \multirow{2}{*}{$<0.001$} & $24.96 \pm 7.65$ & \multirow{2}{*}{0.025} & $0.23 \pm 0.35$ & \multirow{2}{*}{0.008} \\
\hline & Controls & 54 & $2.82 \pm 1.92 *$ & & $18.43 \pm 8.42$ & & $1.93 \pm 4.53$ & \\
\hline
\end{tabular}

Mann-Whitney U-test was used for DNA damage and MN test and t-test for telomere length

*Significant difference between controls with the wild and mutated genotype $(p=0.021)$ 
Table 3 GSTP1 polymorphism and age effects on the biomarkers between mutated and wild genotype groups in the workers and controls

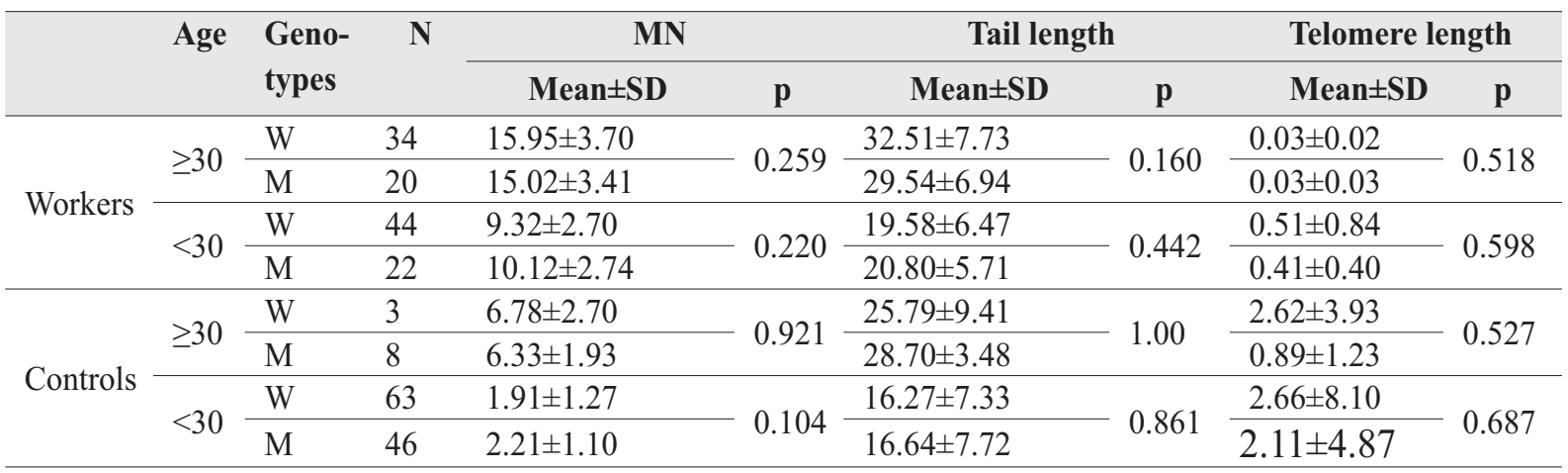

Mann-Whitney U-test was used for DNA damage and MN test, and t-test for telomere length ( $p=0.05)$

$W=$ wild genotype; $M=$ mutated genotype

$(p=0.004)$ (Table 4). Duration of employment was divided in more than or less than 5 years and showed a significant effect on $\mathrm{MN}$ frequency $(\mathrm{p}<0.001)$, comet tail length $(\mathrm{p}<0.001)$, and telomere length shortening $(\mathrm{p}=0.001)($ Tables 4,5 and 6$)$.

\section{DISCUSSION}

GSTP1 gene seems to play particular role in the detoxification of inhaled toxicants $(14,15)$. However, the mutated GSTP 1 variant seems to be less effective in detoxification than the wild genotype $(16,17)$. Some studies demonstrated that gene variants can influence the effect of occupational exposure. For instance, Heuser et al. (18) showed that the mutated genotype (Ile/Val or Val/Val) was associated with greater DNA damage in Brazilian footwear workers than the wild (Ile/Ile) genotype (19). These studies point to an interaction between the exposure and genotype.

In our study, GSTP 1 polymorphism was not associated with significantly higher MN frequency, comet tail length, and lower telomere length in the exposed workers and controls in the age groups, and we only found a significant difference in $\mathrm{MN}$ frequency of controls.

Previous studies $(18,20,21)$ reported that the alteration of the transcriptional activation of enzyme played an important role in ageing. Even though age undeniably contributed to genome damage in our study, this can not be said for GSTP1 polymorphism. However, the results of this study as well as those presented by Heuser et al. (18) must be interpreted with caution because of the relatively small number

Table 4 Results of MN test in subgroups of workers and controls with different socio-demographic factors

\begin{tabular}{|c|c|c|c|c|c|c|c|}
\hline \multirow{2}{*}{ Group } & \multicolumn{2}{|c|}{ Workers } & \multicolumn{2}{|c|}{ Controls } & \multicolumn{2}{|c|}{ All subjects } & \multirow[b]{2}{*}{$\mathbf{p}$} \\
\hline & $\mathbf{N}$ & Mean \pm SD & $\mathbf{N}$ & Mean \pm SD & $\mathbf{N}$ & Mean \pm SD & \\
\hline All subjects & 120 & $13.19 \pm 0.77^{\mathrm{a}}$ & 120 & $3.11 \pm 0.96^{\mathrm{b}}$ & 240 & $8.15 \pm 0.60$ & $<0.001$ \\
\hline Smokers & 59 & $13.69 \pm 1.05$ & 30 & $3.21 \pm 1.30$ & 89 & $8.45 \pm 0.90$ & \multirow{2}{*}{0.494} \\
\hline Non-smokers & 61 & $12.70 \pm 0.89$ & 90 & $3.01 \pm 1.02$ & 151 & $7.85 \pm 0.72$ & \\
\hline Educated & 24 & $13.59 \pm 1.31$ & 105 & $3.41 \pm 0.75$ & 129 & $8.50 \pm 0.86$ & \multirow{2}{*}{0.590} \\
\hline Non-educated & 96 & $12.80 \pm 0.55$ & 15 & $2.81 \pm 1.59$ & 111 & $7.80 \pm 0.91$ & \\
\hline Drinkers & 12 & $13.51 \pm 1.13$ & 3 & $3.42 \pm 1.25$ & 3 & $8.47 \pm 1.00$ & \multirow{2}{*}{0.520} \\
\hline Non-drinkers & 108 & $12.88 \pm 0.65$ & 117 & $2.79 \pm 0.90$ & 117 & $7.83 \pm 0.46$ & \\
\hline Malay & 65 & $11.85 \pm 1.03$ & 78 & $3.32 \pm 1.02$ & 143 & $7.58 \pm 0.97^{\mathrm{a}}$ & \multirow{3}{*}{0.004} \\
\hline Chinese & 45 & $13.59 \pm 0.79$ & 33 & $2.30 \pm 1.08$ & 78 & $7.95 \pm 0.72^{\mathrm{a}}$ & \\
\hline Indian & 10 & $14.15 \pm 1.94$ & 9 & $3.70 \pm 2.24$ & 19 & $8.92 \pm 1.20^{\mathrm{b}}$ & \\
\hline Working time $>5$ years & 37 & $14.38 \pm 0.93^{\mathrm{a}}$ & & - & & & \\
\hline Working time $<5$ years & 83 & $11.18 \pm 0.79^{\mathrm{b}}$ & & - & & & $<0.001$ \\
\hline
\end{tabular}

Means with different superscripts are significant at $p<0.05$ 
Table 5 Result of comet assay (tail length) in subgroups of workers and controls with different socio-demographic factors

\begin{tabular}{|c|c|c|c|c|c|c|c|}
\hline \multirow{2}{*}{ Group } & \multicolumn{2}{|c|}{ Workers } & \multicolumn{2}{|c|}{ Controls } & \multicolumn{2}{|c|}{ All subjects } & \multirow[b]{2}{*}{$\mathbf{p}$} \\
\hline & $\mathbf{N}$ & Mean \pm S.D. & $\mathbf{N}$ & Mean \pm S.D. & $\mathbf{N}$ & Mean \pm S.D. & \\
\hline All subjects & 120 & $26.10 \pm 2.08^{\mathrm{a}}$ & 120 & $19.97 \pm 2.59^{b}$ & 240 & $23.03 \pm 1.61$ & $<0.001$ \\
\hline Smokers & 59 & $27.73 \pm 2.83$ & 30 & $22.33 \pm 3.48$ & 89 & $21.04 \pm 1.94$ & \multirow{2}{*}{0.068} \\
\hline Non-smokers & 61 & $24.47 \pm 2.40$ & 90 & $17.61 \pm 2.76$ & 151 & $25.03 \pm 2.43$ & \\
\hline Educated & 24 & $26.13 \pm 3.52$ & 105 & $20.80 \pm 2.01$ & 129 & $23.47 \pm 2.31$ & \multirow{2}{*}{0.959} \\
\hline Non-educated & 96 & $26.07 \pm 1.49$ & 15 & $19.13 \pm 4.27$ & 111 & $22.60 \pm 2.44$ & \\
\hline Drinkers & 12 & $27.17 \pm 3.03$ & 3 & $21.04 \pm 3.35$ & 3 & $24.11 \pm 2.70$ & \multirow{2}{*}{0.667} \\
\hline Non-drinkers & 108 & $25.02 \pm 1.76$ & 117 & $18.90 \pm 2.41$ & 117 & $21.96 \pm 1.24$ & \\
\hline Malay & 65 & $25.33 \pm 2.75$ & 78 & $19.25 \pm 2.74$ & 143 & $22.29 \pm 2.59$ & \multirow{3}{*}{0.093} \\
\hline Chinese & 45 & $26.11 \pm 2.12$ & 33 & $17.63 \pm 2.90$ & 78 & $21.87 \pm 1.93$ & \\
\hline Indian & 10 & $26.86 \pm 5.20$ & 9 & $23.03 \pm 6.03$ & 19 & $24.95 \pm 3.24$ & \\
\hline Working time $>5$ years & 37 & $32.05 \pm 1.80^{\mathrm{a}}$ & & - & & & \multirow{2}{*}{$<0.001$} \\
\hline Working time $<5$ years & 83 & $21.47 \pm 1.53^{b}$ & & - & & & \\
\hline
\end{tabular}

Means with different superscripts are significant at $p<0.05$

Table 6 Result of telomere length shortening biomarker in subgroups of workers and controls with different socio-demographic factors

\begin{tabular}{|c|c|c|c|c|}
\hline Group & $\begin{array}{c}\text { Workers } \\
\text { (N) }\end{array}$ & $\begin{array}{c}\text { Controls } \\
\text { (N) }\end{array}$ & $\begin{array}{l}\text { All subjects } \\
(\mathbf{N})\end{array}$ & p \\
\hline All subjects & 120 & 120 & 240 & 0.046 \\
\hline Smokers & 59 & 30 & 89 & \multirow{2}{*}{0.377} \\
\hline Non-smokers & 61 & 90 & 151 & \\
\hline Educated & 24 & 105 & 129 & \multirow{2}{*}{0.437} \\
\hline Non-educated & 96 & 15 & 111 & \\
\hline Drinkers & 12 & 3 & 3 & \multirow{2}{*}{0.683} \\
\hline Non-drinkers & 108 & 117 & 117 & \\
\hline Malay & 65 & 78 & 143 & \multirow{3}{*}{0.814} \\
\hline Chinese & 45 & 33 & 78 & \\
\hline Indian & 10 & 9 & 19 & \\
\hline Working time $>5$ years & 37 & & & \multirow{2}{*}{0.001} \\
\hline Working time $<5$ years & 83 & & & \\
\hline
\end{tabular}

of exposed and control subjects involved in each genotype and age subgroup.

GSTP1 is a major enzyme that is involved in the inactivation and detoxifying of cytotoxic environmental substances like benzo(a)pyrene diol epoxide and acrolein $(9,22)$. GSTP1 has a dual role in DNA damage in occupational and environmental exposure (23). There seems to be a controversy about its ability to alter the early effects of toxic exposure on DNA damage biomarkers (24). Our study confirms this controversy. Interpretation is further complicated by the socio-demographic factors $(25,26)$, as they influence the level of genome damage together with gene polymorphism.

While we were not able to isolate the influence of gene polymorphism, our results do not entirely exclude this possibility. The case in point are the significant ethnic differences in MN frequency regardless of occupational exposure (Table 4), which imply the influence of gene polymorphism on cell protection against genome damage along with the living/ occupational environment (27).

\section{CONCLUSION}

Unlike earlier findings, our results suggest that GSTP1 polymorphism does not contribute significantly to genome damage in the exposed workers, but do confirm the significant influence of the occupational setting and ageing. However, the interpretation of our results is limited by a relatively small number of 
subjects involved, and further investigation is needed to elucidate the influence of the interaction between gene polymorphism and environmental factors on genome damage.

\section{Acknowledgment}

The authors gratefully acknowledge the cooperation of all volunteers who participated in this study.

\section{REFERENCES}

1. Verger A, Crossley M. Chromatin modifiers in transcription and DNA repair. Cell Mol Life Sci 2004;61:2154-62.

2. Wojda A, Witt M. Manifestations of aging at the cytogenetic level. J Appl Genet 2003;44:383-99.

3. Harman D. The aging process. Proc Natl Acad Sci USA 1981;78:7124-8.

4. Harman D. The aging process: Major risk factor for disease and death. Proc Natl Acad Sci USA 1991;88:5360-3.

5. Shawi M, Autexier C. Telomerase, senescence and ageing. Mech Ageing Dev 2008;129:3-10

6. Ono T, Uehara Y, Saito Y, Ikehata H. Mutation theory of aging, assessed in transgenic mice and knockout mice. Mech Ageing Dev 2002;123:1543-52.

7. Allan JM, Wild CP, Rollinson S, Willett EV, Moorman AV, Dovey GJ, Roddam PL, Roman E, Cartwright RA, Morgan GJ. Polymorphism in glutathione S-transferase P1 is associated with susceptibility to chemotherapy-induced leukemia. Proc Natl Acad Sci USA 2001;98:11592-7.

8. Lai R, Crevier L, Thabane L. Genetic polymorphisms of glutathione S-transferases and the risk of adult brain tumors: a meta-analysis. Cancer Epidemiol Biomarkers Prev 2005; 14:1784-90.

9. Krapels IP, Raijmakers-Eichhorn J, Peters WH, Roelofs HM, Ras F, Steegers-Theunissen RP, Eurocran Gene-Environment Interaction Group. The I105V polymorphism in glutathione S-transferase P1, parental smoking and the risk for nonsyndromic cleft lip with or without cleft palate. Eur J Hum Genet 2008;16:358-66.

10. Bolognesi C, Lando C, Forni A, Landini E, Scarpato R, Migliore L, Bonassi S. Chromosomal damage and ageing: effect on micronuclei frequency in peripheral blood lymphocytes. Age Ageing 1999;28:393-7.

11. Beliën JA, Copper MP, Braakhuis BJ, Snow GB, Baak JP. Standardization of counting micronuclei: definition of a protocol to measure genotoxic damage in human exfoliated cells. Carcinogenesis 1995;16:2395-400.

12. Cawthon RM. Telomere measurement by quantitative PCR. Nucleic Acids Res 2002;30:e47.

13. Harries LW, Stubbins MJ, Forman D, Wolf CR. Identification of genetic polymorphisms at the glutathione S-transferase $\mathrm{Pi}$ locus and association with susceptibility to bladder, testicular and prostate cancer. Carcinogenesis 1977;18:641-4.

14. Saarikoski ST, Voho A, Reinkainen M, Antilla S, Karjalainen A, Malaveille C, Vainio H, Husgavfel-Pursianinen K, Hirvonen A. Combined effect of polymorphic GST genes on individual susceptibility to lung cancer. Int J Cancer 1998;77:516-21.

15. Hirvonen A. Gene-environment interaction and biological monitoring of occupational exposures. Toxicol Appl Pharmacol 2005;207:329-35.

16. Watson MA, Stewart RK, Smith GB, Massey TE, Bell DA. Human glutathione S-transferase P1 polymorphisms: relationship to lung tissue enzyme activity and population frequency distribution. Carcinogenesis 1998;19:275-80.

17. Miller DP, Asomaning K, Liu G, Wain JC, Lynch TJ, Neuberg $\mathrm{D}, \mathrm{Su} \mathrm{L}$, Christiani DC. An association between glutathione S-transferase P1 gene polymorphism and younger age at onset of lung carcinoma. Cancer 2006;107:1570-7.

18. da Silva J, Moraes CR, Heuser VD, Andrade VM, Silva FR, Kvitko K, Emmel V, Rohr P, Bordin DL, Andreazza AC, Salvador M, Henriques JAP, Erdtmann B. Evaluation of genetic damage in a Brazilian population occupationally exposed to pesticides and its correlation with polymorphisms in metabolizing genes. Mutagenesis 2008;23:415-22.

19. Norppa H. Genetic susceptibility, biomarkers response, and cancer. Mutat Res 2003;544:339-48.

20. Heuser VD, Erdtmann B, Kvitko K, Rohr P, da Silva J. Evaluation of genetic damage in Brazilian footwear-workers: Biomarkers of exposure, effect, and susceptibility. Toxicology 2007;232:235-47.

21. Perez-Cadahı B, Laffon B, Valdiglesias V, Pasaro E, Mendez J. Cytogenetic effects induced by Prestige oil on human populations: The role of polymorphisms in genes involved in metabolism and DNA repair. Mutat Res 2008;653:11723.

22. Munaka M, Kohshi K, Kawamoto T, Takasawa S, Nagata N, Itoh H, Oda S, Katoh T. Genetic polymorphisms of tobaccoand alcohol-related metabolizing enzymes and the risk of hepatocellular carcinoma. J Cancer Res Clin Oncol 2003;129:355-60.

23. Liu YJ, Huang PL, Chang YF, Chen YH, Chiou YH, Xu ZL, Wong RH. GSTP1 Genetic Polymorphism Is Associated with a Higher Risk of DNA Damage in Pesticide-Exposed Fruit Growers. Cancer Epidemiol Biomarkers Prev 2006;15:65966.

24. Palma S, Cornetta T, Padua L, Cozzi R, Appolloni M, Ievoli E, Testa A. Influence of glutathione S-transferase polymorphisms on genotoxic effects induced by tobacco smoke. Mutat Res 2007;633:1-12.

25. Kirsch-Volders M, Mateuca RA, Roelants M, Tremp A, Zeiger E, Bonassi S, Holland N, Chang WP, Aka PV, DeBoeck M, Godderis L, Haufroid V, Ishikawa H, Laffon B, Marcos R, Migliore L, Norppa H, Teixeira JP, Zijno A, Fenech M. The Effects of GSTM1 and GSTT1 polymorphisms on micronucleus frequencies in human lymphocytes in vivo. Cancer Epidemiol Biomarkers Prev 2006;15:1038-42.

26. Garte S, Taioli E, Popov T, Kalina I, Sram R, Farmer P. Role of GSTT1 deletion in DNA oxidative damage by exposure to polycyclic aromatic hydrocarbons in humans. Int J Cancer 2006;120:2499-503.

27. Zhan P, Wang J, Zhang Y, Qiu LX, Zhao SF, Qian Q, Wei SZ, Yu LK, Song Y. CYP2E1 Rsa I/Pst I polymorphism is associated with lung cancer risk among Asians. Lung Cancer 2010;69:19-25 


\section{Sažetak}

\section{PRIDONOSI LI POLIMORFIZAM GENA GSTPI OŠTEĆENJU GENOMA UZROKOVANOM STARENJEM I PROFESIONALNOM IZLOŽENOSTI?}

Na populaciji radnika zaposlenih u radionicama za popravak automobila koji su svakodnevno izloženi različitim vrstama potencijalnih mutagena istražili smo utjecaj polimorfizma gena GSTP1 na vrijednosti biomarkera starenja, uključujući pojavu mikronukleusa (MN), dužinu repa kometa te relativnu dužinu telomera. Analize su provedene na stanicama bukalne sluznice, skupljenim od izloženih ispitanika i odgovarajuće neizložene (kontrolne) populacije. Uzorci su analizirani primjenom citogenetičkih i molekularnobioloških metoda, uključujući polimorfizam restrikcijskih fragmenata na osnovi njihove duljine (engl. restriction fragment length polymorphism, RFLP), MN-test, komet-test, i lančanu reakciju polimerazom u stvarnom vremenu (engl. real-time $P C R$ ). Dobiveni nalazi potvrđuju da izloženost radnika mutagenima oštećuje njihovu DNA, ali nisu pokazali da polimorfizam gena GSTP1 značajno utječe na razinu oštećenja DNA. Zbog malog broja ispitanika uključenog u ovo istraživanje za bolje razumijevanje odnosa između polimorfizma gena GSTP1 i oštećenja DNA potrebna su daljnja istraživanja, i na profesionalno izloženim ispitanicima i na ispitanicima kontrolne populacije.

KLJUČNE RIJEČI: dužina repa kometa, dužina telomere, glutation S-transferaze, PCR, RFLP, stanice bukalne sluznice, učestalost mikronukleusa

\section{CORRESPONDING AUTHOR:}

Patimah Ismail

Faculty of Medicine and Health Sciences

Universiti Putra Malaysia

Serdang, Selangor, Malaysia

E-mail:patimahismail@gmail.com 